\title{
Research on the Teaching Model of College English Reading Based on Flipped Classroom
}

\author{
Wei-qiang Qiu \\ School of Foreign Language \\ Jiangxia University \\ Fuzhou, 350108, China
}

\begin{abstract}
Flipping classroom is the teaching practice paradigm of the integration of modern information technology and education. By analyzing the advantages of the flipping classroom teaching model and combining the characteristics of college English reading teaching, this study applies the flipped classroom teaching model to college English reading teaching, constructs the flipped classroom teaching model of college English reading including knowledge transmission before class, knowledge internalization in class and extended reading after Class. This study also makes an empirical research on the practical application of this teaching model .The aim of the study is to improve students' English autonomous learning ability and optimize the classroom te aching of college English reading.
\end{abstract}

Keywords-flipped classroom; autonomous learning; college English reading teaching; teaching model

\section{INTRODUCTION}

With the development of information technology and the proposal of "Internet +" strategy, advanced education informatization develops rapidly. According to the College English Teaching Guide, issued by the Ministry of Education, "colleges and universities should encourage English teachers to reform traditional English classroom teaching through the construction and use of micro-course, MOOCs and other teaching resources, and cultivate students' independent learning ability and comprehensive English ability through the implementation of flipped classroom teaching model". Flipped classroom, a new teaching model, can guide students to study independently, cultivate and enhance students' independent learning ability[1], which is of great value to effectively improve the quality of college English teaching and also reflects the requirements of College English Teaching Guide. At the same time, flipped classroom teaching model, as a model of deep integration of curriculum teaching and information technology has also become a hot topic in the reform of college English teaching in the context of the information age. The introduction of flipping classroom model in teaching practice can not only conform to the trend of educational development in the information age, but also create convenience for students to learn. Therefore, it is very necessary to apply flipped classroom to the practice of college English teaching reform and explore a new reading teaching model to improve the teaching effect of college English

Fund project: 2017 Educational research project for young and middleaged teachers of Fujian Province (Special project for college foreign language teaching reform)" Construction of college English autonomous learning model based on flipped classroom" (No. : JZ 170086); Horizontal fund project of Fujian Jiangxia University (No. : JXH2017022) reading and the reading ability of students.

\section{THE CONNOTATION OF THE FLIPPED CLASSROOM}

The flipped classroom model, which originated at Woodland Park high school in the United States, chemistry teachers, Jonathan Berman and Aaron Sams, found some students failed to take part in normal classroom activities and failed to keep up with the curriculum. In order to solve this problem, they made the operation process of PowerPoint presentation video with the screen recording software and uploaded it to the Internet for students to download and study, providing convenience for students to learn. Students can use these materials to realize free and independent learning in extracurricular time. Teachers can focus on solving students' difficult problems in class and realize effective interaction between teachers and students, so as to promote students' participation in class and improve the teaching effectiveness.[2] Flipped Classroom is a new type of teaching model, which refers that in the information environment, the teachers provide teaching video as the main form of learning resources and students finish watching and learning the teaching video resources before class, teachers and students finish problem answering, collaborative inquiry and interactive communication together in class [3]. The biggest difference between flipped classroom and traditional teaching model lies in that under the support of information technology, students can use high-quality education resources to acquire and learn new knowledge in extracurricular time. In the classroom, the role of teachers and students has also changed. Teachers guide and promote students' learning process by some ways such as answering questions. Students become the main part of the class, and realize in-depth learning, cultivate thinking ability through learning strategies such as report, discussion or debate, and complete internalization of knowledge. The flipping classroom teaching model overturns the traditional education model and teaching method, puts the knowledge teaching process before the class, and the knowledge internalization process in the classroom, thus realizes the reversal of teaching process[4]. In the flipped classroom teaching model, teaching resources can be Shared on the Internet, which breaks the limitation of traditional teaching model to a certain extent. Teaching is more open and enlightening, and flipped classroom teaching model is a teaching model that highlights students' independent learning and can be effectively promote the improvement of teaching efficiency[5].The rational application of flipped classroom teaching model in college English 
teaching can promote the optimal design of college English reading teaching activities.

\section{ADVANTAgES OF FLIPPED CLASSROOM IN COLLEGE ENGLISH READING TEACHING}

\section{A. It helps to improve the efficiency of classroom teaching.}

The flipping classroom teaching form changed from "classroom explanation and homework after class" to "preclass study and classroom inquiry". Before class, students watch videos, consult materials and complete tasks to make a preliminary understanding of what they will learn. In class, they solve questions and internalize their knowledge by answering questions, discussing and practicing. In the flipping classroom, the teacher is transformed from a person of imparting knowledge into a learning instructor. Since the transfer of knowledge is completed before class, the teacher has sufficient time to conduct teacher-student interaction, and the interaction between students and students, maximizing the goal of knowledge internalization and it is beneficial for students to construct knowledge system actively.

\section{B. It helps to improve students' autonomous learning ability}

The flipped classroom of college English reading raises higher requirement for students' autonomous learning ability and self-discipline[6]. Before class, students can watch the micro-video assigned by teachers at anytime and anywhere, they can repeatedly watch as needed until they understand the language point. In this process, students are the leading role, teachers are the supporting role, and the effectiveness of students' autonomous learning of micro-video before class directly affects the implementation and effectiveness of the process of knowledge internalization in class. In class, students are highly involved in various activities, and those with poor self-learning ability are easily lost in the flipped classroom teaching model. After they taste the bitter fruit, students will certainly make efforts to improve their autonomous learning ability, constantly urge themselves to earnestly study teaching micro-video after class and ask questions online in time, so as to make full preparation for the smooth completion of homework in class.

\section{It helps to improve teachers' modern education technical skills}

"Technology cannot replace teachers," says Ray Clifford, a linguist." but teachers who use technology can replace teachers who don't." Nowadays, the development of information technology has raised new and higher requirements for college teachers. Teachers should make full use of frontier technology to construct teaching and learning in the information age, and consciously improve their own modern education technical skills. The premise of flipped classroom is the production of teaching micro-video. Teachers must learn relevant technical skills in order to record better teaching video. In the information age, what teachers lack are not resources, but how to make good use of them.

\section{THE TEACHING PROCESS OF READING BASED ON THE FLIPPED} CLASSROOM MODEL

Based on the domestic and foreign flipped classroom teaching models and the characteristics of college English courses and current situation of reading teaching, this study constructs flipped classroom teaching models which includes three stages: knowledge transmission before class, knowledge internalization in class and extended reading after Class.

\section{A. Transmission of knowledge before class}

In flipping class teaching, the students watch the teaching video on the network platform to realize the transmission of knowledge. The teacher should choose the appropriate reading content and make the teaching video according to the analysis of teaching target, teaching content and teaching object. The teaching video before class is an important part of the flipping class, and the teaching effect can not be guaranteed with the lack of high quality micro-lesson video. Teachers in this link can make teaching videos around the following points: first of all, the teaching video should focus on a specific knowledge point, improve the accuracy of learning goals, avoid multiple and complex learning tasks. Secondly, the difficulty of text material should be moderate, and the degree of difficulty should conform to the theory of "proximal development zone", and promote students to construct new knowledge structure on the basis of existing knowledge framework. Third, the teaching video should be interesting, which can arouse students' interest and desire to learn, arouse students' participation in class, and promote students' thinking. Taking English reading teaching as an example, the teaching video before class mainly introduces: the key words, phrases, sentences, identification of theme ideas, reading strategies. The reading steps are as follows: first, learn the important new words, phrases and sentences in the article to clear up the reading barrier; secondly, clarify the context of the article, understand the general idea of the article. Third, teach reading strategies.

In order to detect the students' autonomous learning before class, teachers can arrange the teaching tasks according to the teaching objectives and the contents of the video. It is intended to examine students' understanding of video content and prepare for the internalization of classroom knowledge. According to the reading goal, the teacher can set up some simple answer questions, ask the students to answer after watching the video, and send the answer to the teacher via WeChat. Teachers should consider the existing knowledge structure of students and reasonably design the difficulty and quantity of tasks. Autonomous learning video and completing the tasks before class is a personalized learning model, which can help exertion of individual potential, and make the learners get a successful experience and satisfaction. Especially for the students who can't keep up with the progress of the class, the pre-class learning process is an important way to make up for the lack of knowledge, improve the reading effect, and gradually increase the confidence and interest.

\section{B. Knowledge internalization stage}

According to constructivism theory, knowledge acquisition is the process of meaning construction by learners in a certain situation through interpersonal cooperation activities. 
Constructivism emphasizes the situation of learning, knowledge and wisdom, and holds that knowledge cannot exist abstractly from the active situation, and that learning should be combined with situational social practice [7]. This point is especially prominent in flipped classroom of college English reading.

The teaching steps designed at this stage are as follows: First, the teacher can test the effect of the students' pre-class learning video through pre-arranged questions, and let the students discuss it together in groups, and then select representatives from each group to speak. For example, students can explain a reading skill or retell an arranged reading article. According to the content of the group speech, the teacher can understand the students' understanding of the problem, then give the corresponding guidance, and emphasize the main points of knowledge and repeat learning content through the final summary. Second, to create the situation, improve the reading comprehension effect. Teachers use multimedia to play music and news via audio or video, create situational patterns that allow students to deepen their understanding of the reading material by understanding the background. Situational setting can further enhance students' interest, enhance students' reading motivation and sense of expectation, and stimulate students' brain to enter the process of active knowledge construction. Third, further explain vocabulary, discuss and train reading strategies and methods.. Clearing vocabulary barriers is the primary condition for improving the effect of reading comprehension. Before class, students have already understood the vocabulary in the teaching task through the video; teachers can further explain the meaning and usage of these words in class, and then help students consolidate these words through various activities, such as guessing words, filling in blanks. Fourth, deep reading. Teachers can help students master the structure of the text and understand the logical structure between paragraphs by text analysis with students. It can help students to find and use the connectives that indicate the logical relationship in an interactive way.

Constructivism holds that teachers should not be the conveyors of knowledge, but the organizers and coordinators of classroom activities. In this stage, some key paragraphs can also be studied in class, and the students can discuss or debate an idea in groups. In the discussion, students can not only study together, solve problems together, but also understand the reading strategies and discussion methods of other students, so as to improve their reading skills and thinking ability and achieve the purpose of internalizing their knowledge. Teachers, as participants in class discussions, should also participate in the students' discussions, which is not only helpful to broaden the students' thinking and deepen students' understanding of reading materials, also promote the internalization and construction of students' knowledge.

\section{Extended reading after class}

On the one hand, extended reading after class complements the deficiency of students' learning in class, on the other hand, it also consolidates and extends the knowledge learned in class, and promotes the cultivation of students' speculative language ability.

\section{1) Extended reading training}

According to learning content before class and the internalization activities carried out in the class, teachers can design relevant reading expansion tasks around the reading theme, using resources such as the Internet or extra-curricular reading books to further increase students' depth and breadth of reading. The extended reading tasks after class can be designed in modules, including language knowledge, background information, textual structure and open problem modules. Teachers can choose after-class reading materials based on unit topics, background information and students' reading ability. A large amount of English reading can not only cultivate students' reading habits and language sense, broaden their horizons and expand the scope of knowledge, but also help them to lay a solid foundation of language skills and improve their comprehensive reading ability.

\section{2) Summary and evaluation}

Timely summary and evaluation not only ensure the smooth completion of the teaching process, but also test the teaching quality and level. The evaluation of flipped classroom is multidimensional and diversified, and this process mainly includes four dimensions of evaluation: first, students' selfevaluation. Namely, students' summary and evaluation of their own learning activities. Through observation, interview, discussion and other methods, teachers guide students to summarize and reflect on the learning process, such as how well the tasks are completed in the three learning processes: before, during and after class, as well as whether students master the language form and language ability required by learning objectives. Second, Peer assessment. In other words, teachers organize students to grade the completion of classroom tasks of each group, so as to enhance the sense of competition and teamwork, and promote students' continuous progress in mutual learning. Third, mutual evaluation between teachers and students. In the evaluation, teachers should try their best to hold a positive attitude towards students' learning, encourage and praise students more, and give them a sense of achievement. At the same time, they should point out and correct their deficiencies and guide them correctly. Students also evaluate teachers, such as teachers' arrangement of preclass tasks, control of class, and organization of instructional mode. Fourth, teachers' self-evaluation. The evaluation includes whether the design of the three teaching processes (before, during and after class) is reasonable, whether the teaching objectives have been achieved, whether the students' language ability has been improved .Through the evaluation and reflection of these aspects; teachers improve and perfect the teaching design of reading.

\section{CONCLUSION}

The flipping class teaching model reverses the two stages of knowledge transfer and knowledge internalization in traditional teaching, changes the traditional teaching methods and learning methods of college English reading, reconstructs the learning process and creates a student-centered classroom. This teaching model can promote the teaching of English reading from teacher-centered to student-centered, enrich students' reading skills, help to cultivate students' autonomous learning ability, and make them gradually form good reading 
habits, so that they can effectively improve reading ability. This model realizes the deep integration of modern information technology and college English teaching, and optimizes the teaching of college English reading, changes the concept of college English teaching, can effectively promote the reform and development of college English reading teaching.

\section{REFERENCES}

[1] Baker,J.W. The classroom flip: Using web course management tools to become the guide by the side[A].In Chambers,J.A.(eds.). The 11th International Conference on College Teaching and Learning [C].Jacksonville:Florida, 2000:9-17
[2] Jonathan Bergmann\&Aaron Sams.Flip Your Classroom:Reach Every Student in Every Class Every Day [M] .America:International Society for Technology in Education, 2012.

[3] Zhong, X. L., Song, S. Q., \& Jiao, L. Z. Research on Teaching Design Based on "Flipped Classroom" Concept in Information Environment. Open Education Research,2013 (1): 55-64

[4] Gannod, G. C. et al. Using the Inverted Classroom to Teach Soft ware Engineering [J]. ICSE 2008( 8) : 125-129.

[5] Lv, L. S., \& He, G. D. Reflection on Influence of Information Technology Based College English Autonomous Learning Mode on Students' Non-intellectual Factors. Shandong Foreign Language Teaching Journal, 2013 (4): 160-187

[6] Zhang Jinlei;W;ng Ying; Zhang Baohui; Flipped classroom teaching mode [J] Journal of distance education 2012 (8): 46-51

[7] Lin Chongde. Educational Psychology [M]. Beijing: people's Education Press. 2000. 